\title{
Obstructive sleep apnea is a risk comorbidity for COVID-19 fatality: A review. Part I
}

\author{
Leopoldo Rivera-Castaño* \\ Department of Neurology and Sleep Clinic of Hospital Angeles Chihuahua, Chihuahua, Mexico
}

\begin{abstract}
The COVID-19 outbreak caused by the SARS-CoV-2 virus became a pandemic, and since the first cases reported in December 2019 to 28 October 2020, more than 44 million positive cases have been recorded with an accumulated fatality of $1,172,086$ people due to the complication of mild infection of the upper airway to a severe disease of the lower airway, such as the acute respiratory distress syndrome, and death from multiple organ failure. Comorbidities such as age over 40 years, obesity, and diabetes mellitus play an important role in the response inflammatory and immunological that can accelerate the production of pro-inflammatory cytokines causing endothelial dysfunction that produces endotheliitis, hypercoagulability, and fibrinolysis not only at lung level but also in other organs such as the heart and central nervous system. Obstructive sleep apnea (OSA), which has a high prevalence in older adults with obesity, is a risk factor for endothelial dysfunction due to hypoxia that may favor hyper inflammation in response to SARS-CoV-2 and therefore OSA should be considered serious comorbidity for COVID-19 fatality. A review of the pathophysiology of SARS-CoV-2, obesity, and OSA may contribute to have more tools in the prevention and treatment of serious complications of COVID-19.
\end{abstract}

Key words: Obstructive sleep apnea. Coronavirus disease-19. Comorbidities. Risk factors.

\section{La apnea obstructiva del sueño es una comorbilidad de riesgo para la letalidad de COVID-19. Revisión. Parte I}

\section{Resumen}

El brote de COVID-19 causado por el virus SARS-CoV-2 se convirtió en una pandemia y desde los primeros casos reportados en diciembre de 2019 hasta el 28 de octubre de 2020, se han reportado más de 44 millones de casos positivos con una fatalidad acumulada de 1,172,086 personas debido a la complicación de una infección leve de las vías respiratorias superiores, a una enfermedad grave de las vías respiratorias inferiores, como el Síndrome de dificultad respiratoria aguda y muerte por insuficiencia orgánica múltiple. Comorbilidades como la edad mayor de 40 años, la obesidad y la diabetes mellitus juegan un papel importante en la respuesta inflamatoria e inmunológica que puede acelerar la producción de citosinas proinflamatorias provocando disfunción endotelial que produce endotelitis, hipercoagulabilidad y fibrinólisis, no solo a nivel pulmonar sino también en otros órganos como el corazón y el sistema nervioso central. La apnea obstructiva del sueño (AOS), que tiene una alta prevalencia en adultos mayores con obesidad, es un factor de riesgo de disfunción endo-

\section{Correspondence:}

*Leopoldo Rivera-Castaño

E-mail: drleopoldo.rivera@yahoo.com
Available online: 25-05-2021

Rev Mex Neuroci. 2021;22(3):112-123

www.revmexneurociencia.com 1665-5044/ (C) 2019 Academia Mexicana de Neurología A.C. Published by Permanyer. This is an open access article under the CC BY-NC-ND license (http://creativecommons.org/licenses/by-nc-nd/4.0/). 
telial por la hipoxia que puede favorecer la hiperinflamación en respuesta al SARS-CoV-2 y, por tanto, la AOS debe considerarse una comorbilidad grave para la letalidad de COVID-19. Una revisión de la fisiopatología del SARS-CoV-2, Ia obesidad y la AOS puede contribuir a tener más herramientas en la prevención y el tratamiento de las complicaciones graves del COVID-19.

Palabras clave: COVID-19. AOS. Comorbilidades. Factores de riesgo.

\section{Introduction}

Obstructive sleep apnea syndrome (OSAS) is characterized by excessive daytime sleepiness, reporting frequent awakenings due to choking sensations and the sleep companion reports habitual snoring with breathing pauses by the patient during sleep. OSAS is more frequent in men than in women with an increased prevalence between 50 and 70 years of age, particularly in overweight subjects, and is exacerbated by the intake of alcohol or by the use of sedatives before sleep. The most frequent comorbidities related to OSAS are obesity, systemic arterial hypertension, atrial fibrillation, type 2 diabetes mellitus, and a high risk of myocardial infarction or cerebral infarction due to endothelial dysfunction.

The severe acute respiratory syndrome (SARS) pandemic called coronavirus disease (COVID)-19 originated from the infection of a new coronavirus, SARS-coronavirus 2 (SARS-CoV-2), which began as an epidemic outbreak in the province of Wuhan in Hubei, China, with 41 cases between December 08, 2019, and January 02, 2020, and that as of March 11, 2020, is considered a Pandemic by the WHO. It is predominant in the male gender, particularly in adults over 60 years of age, and has an average mortality rate of $6.87 \%$ with a death rate per million inhabitants of 11.5 related to comorbidities that generate endothelial dysfunction such as obesity, arterial hypertension, type 2 diabetes mellitus, chronic respiratory diseases, pathological immunosuppression, or by drugs. However, adult obstructive sleep apnea (OSA) or sleep-related hypoventilation syndromes have not been considered as serious risk factors for the complication of acute respiratory distress syndrome (ARDS) and death.

\section{The COVID-19}

\section{Etiology}

COVID-19 is an infection caused by a new virus, SARS-CoV-2.
Table 1. Baltimore classification of viruses by type of genome

\begin{tabular}{|c|l|}
\hline $\begin{array}{c}\text { DNA virus } \\
\text { Group I } \\
\text { Group II }\end{array}$ & $\begin{array}{l}\text { Viruses possess double-stranded DNA } \\
\text { Viruses possess single-stranded DNA }\end{array}$ \\
\hline $\begin{array}{c}\text { RNA virus } \\
\text { Group III }\end{array}$ & $\begin{array}{l}\text { Viruses possess double-stranded RNA } \\
\text { genomes } \\
\text { Viruses possess positive-sense single- } \\
\text { Group IV } \\
\text { stranded RNA genomes } \\
\text { Viruses possess negative-sense } \\
\text { single-stranded RNA genomes }\end{array}$ \\
\hline DNA or RNA virus & $\begin{array}{l}\text { Viruses possess single-stranded RNA } \\
\text { genomes that replicate through a DNA } \\
\text { intermediate } \\
\text { Group VII }\end{array}$ \\
$\begin{array}{l}\text { Viruses possess double-stranded DNA } \\
\text { genomes and replicate using reverse } \\
\text { transcriptase }\end{array}$ \\
\hline
\end{tabular}

Baltimore David. Expression of Animal Virus Genome. Bacteriological Reviews, 1971. DNA: (deoxyribonucleic acid); RNA: ribonucleic acid; (ss) single-stranded: single chain of DNA or RNA; (ds) double-stranded: two chains of DNA o RNA.

\section{Background}

The SARS-CoV-2 virus belongs to group IV (viral messenger RNA type) because of its genome, according to the Baltimore Classification (Table 1).

SARS-CoV-2 is a virus of the order Nidovirales, of the family Coronoviridae, subfamily Orthocoronavirinae and of the genus Betacoranavirus, to which belongs the SARS-CoV responsible for the severe acute respiratory syndrome in 2003, and the SARS-Middle East respiratory syndrome (MERS) responsible for the Middle Eastern respiratory syndrome in 2012, according to the International Committee on Taxonomy of Viruses (Fig. 1).

- Human coronaviruses (HCoV)-229E. Discovered in 1966. It causes a flu-like respiratory illness in humans.

- HCoV-0C43. Discovered in 1967. It also causes a flu-like respiratory illness in humans.

- SARS-CoV. Caused the severe acute respiratory syndrome epidemic. It was discovered in November 


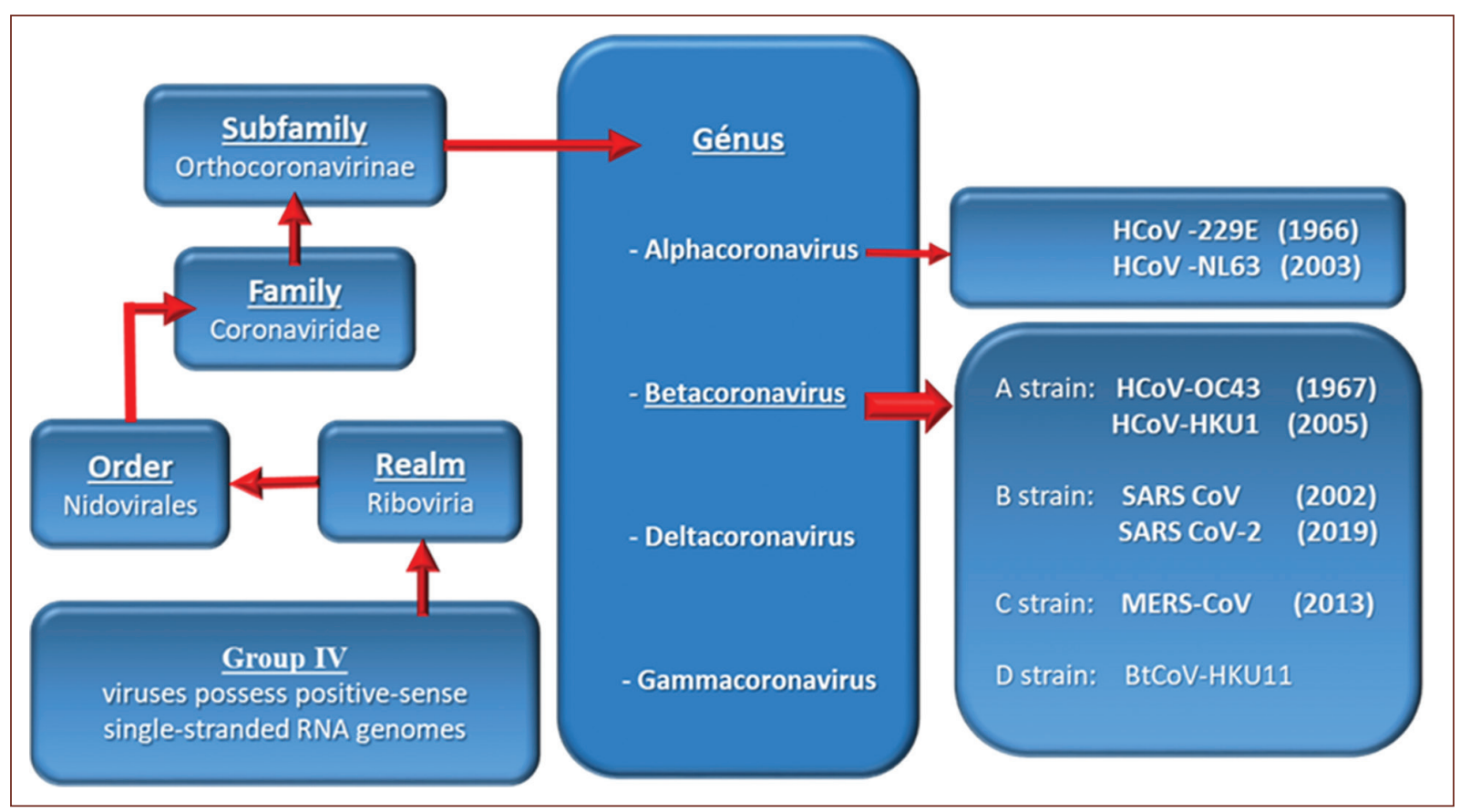

Figure 1. SARS-CoV-2 taxonomy responsible for the 2019 coronavirus disease, called COVID-19.

2002, in the province of Canton, China. It spread to several countries with 8403 cases and 775 deaths reported as of June $5,2003^{1}$.

- HCoV-NL63. It was identified in the Netherlands in 2003 in a child with bronchiolitis.

- HCoV-HKU1. Discovered in 2005 in two patients in the Chinese city of Hong Kong.

- MERS coronavirus (MERS-CoV). Causes Middle Eastern Respiratory Syndrome, an infectious disease first identified in 2012 in Saudi Arabia.

- SARS-CoV-2 was recognized in January 2020 as responsible for a severe acute respiratory syndrome that started in December 2019 in the province of Wuhan, China, and became a pandemic and now an endemic called COVID-19?2.

\section{Structure of the SARS-CoV-2 virus}

As in all coronaviruses, the nucleocapsid and the envelope form the general structure. The nucleocapsid is made up of a nucleus of RNA (short for ribonucleic acid, the genetic material of the virus) with its capsid which is a protein $(\mathrm{N})$ structure either icosahedral or helical formed by a series of monomers called capsomeres, an outer shell of the protein or polyprotein that protects the genetic material of the virus. In the envelope (E) of coronaviruses, there is a membrane glycoprotein (M) of 20-35 kDa, which forms a matrix in contact with the nucleocapsid. In addition, in the envelope $(E)$, there is a $180-220 \mathrm{kDa}$ glycoprotein $(\mathrm{S})$, which forms the spikes or peplomers responsible for adhesion to the host cell and other short projections formed by dimers of the hemagglutinin-esterase (Fig. 2) ${ }^{3}$.

In the specific case of SARS-CoV-2 coronavirus in its spicules, a receptor-binding domain directs the adhesion of the virus to its cellular receptor, the angiotensin-converting enzyme 2 (ACE2). In addition, entry requires preparation of the S-protein by the transmembrane protease, serine 2 (TMPRSS2), which involves excision of the S-protein at the S1/S2 and S2' site allowing the fusion of the viral and cell membranes, a process driven by the S2' subunit (Fig. 3) $)^{4-6}$.

\section{Mechanisms of infection of the SARS-CoV-2}

It has been proven that the mechanism of transmission is person to person, mainly by the respiratory route, through airborne transmission (droplets) which, when coughing, sneezing, or speaking in close proximity to another person, puts the virus in contact with the mucous membranes of the mouth, nose or eyes. The 


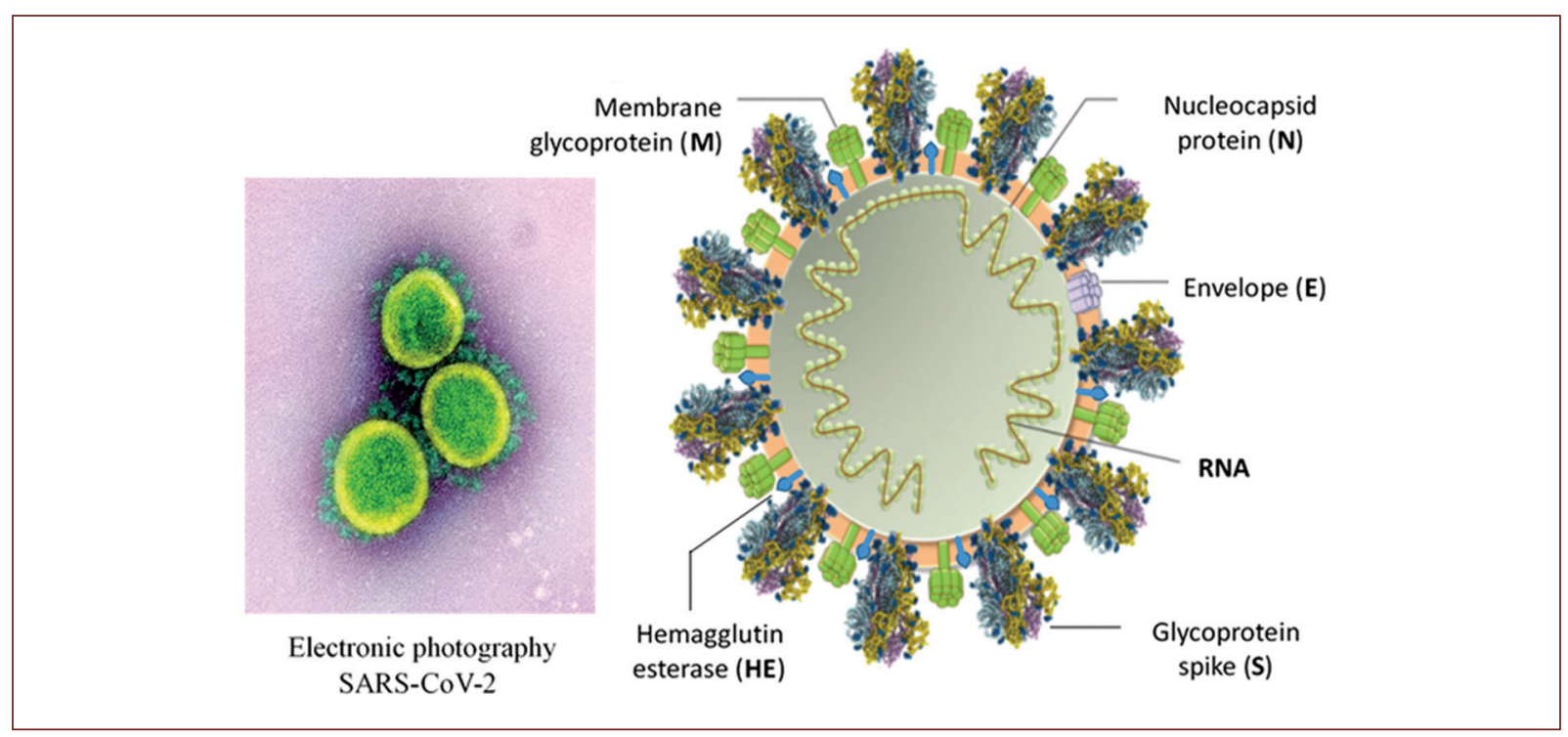

Figure 2. Molecular structure of SARS-CoV-2.

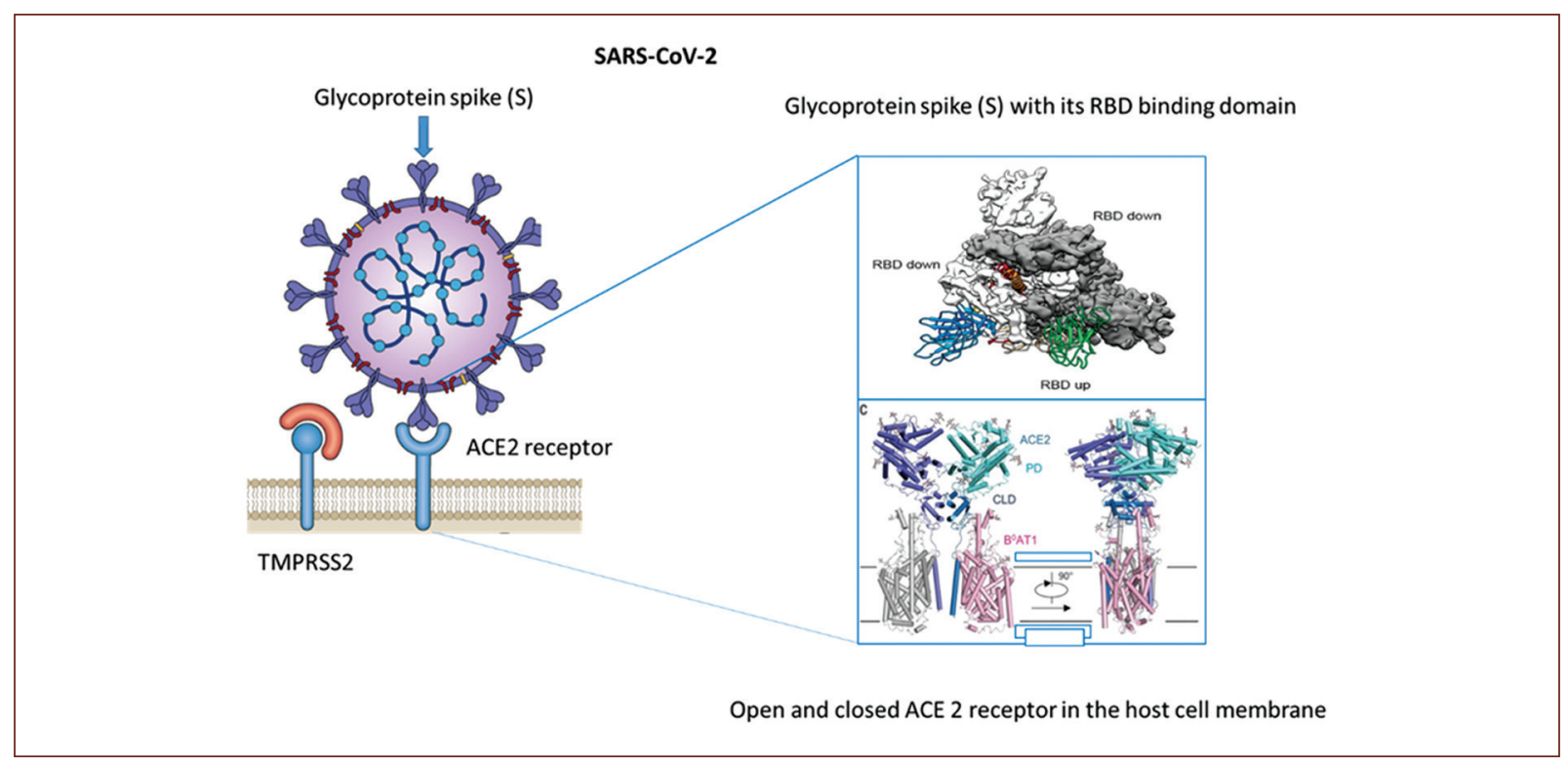

Figure 3. The S glycoprotein adheres to a specific ACE-2 receptor.

range of the droplets when expelled by coughing or sneezing is $<2 \mathrm{~m}$, usually no more than one meter, and they do not persist in the air.

Transmission can also occur by touching surfaces contaminated by the droplets with the hands and then touching the person's eyes, nose, or mouth. Transmission by fomites is also possible. The exact survival time of the virus in the environment is not known, but it is estimated that it may be active on inanimate surfaces for 9 days, with the length of time-varying according to climatic conditions and type of surface. The permanence of viable SARS-CoV-2 on copper, cardboard, stainless steel, and plastic surfaces has been 4, 24, 48, and $72 \mathrm{~h}$, respectively, under experimental conditions at $21-23^{\circ} \mathrm{C}$ and relative humidity of $65 \%$. HCoV is efficiently inactivated in the presence of $62-71 \%$ ethanol, $0.1-0.5 \%$ sodium hypochlorite, and $2 \%$ glutaraldehyde, with a reduction of 2-4 $\log 10$ after 1 min of exposure. 
It has recently been demonstrated that SARS-Cov-2 remains in aerosols under experimental conditions at $21-23^{\circ} \mathrm{C}$ and relative humidity of $65 \%$ with an average half-life of $2.7 \mathrm{~h}$. Airborne or aerosol transmission (capable of transmission over a distance of more than $2 \mathrm{~m}$ ) could not be demonstrated in the SARS-CoV-2 outbreak in China. However, it is believed that it could occur during the performance of invasive medical procedures of the respiratory tract. Although the virus has been isolated in human feces, the hypothesis of fecal-oral transmission has not been demonstrated?

\section{Capacity for contagion}

It seems that the possibility of contagion is greater in the $1^{\text {st }}$ days with symptoms and is reduced in the later days, although it is a hypothesis that needs more testing. The infection rates caused by each infected person are highly variable, depending on the geographical location and the control measures in place, ranging from $0.45 \%$ to $5 \%$ of contacts. In public health, the basic reproductive number $(\mathrm{Ro})$ is calculated, by which the speed with which a disease can spread in a population is estimated. SARS-CoV-2 is the causative agent of the ongoing co COVID pandemic. In the case of SARS-CoV-2, initial estimates of the early dynamics of the outbreak in Wuhan, China, suggested a doubling time of the number of infected persons of 6-7 days and a basic reproductive number (Ro) of 2.2-2.7. Recently assuming a serial interval of 6-9 days, Sanche et al., calculated a median Ro value of 5.7 (95\% confidence interval $[\mathrm{Cl}] 3.8-8.9)^{8,9}$.

\section{SARS-CoV-2 replication mechanisms}

The coronavirus replication cycle is divided into several steps: fixation and entry, translation of viral replicase, transcription, and replication of the genome, translation of structural proteins with assembly and release of virions ${ }^{10}$ :

1. It is initiated by the binding of the S-protein to a specific receptor on the host cell membrane. MERS-CoV uses dipeptidyl peptidase 4 as a receptor, unlike the SARS CoV and SARS-CoV-2 viruses which specifically target the ACE2 receptor and through the involvement of the TMPRSS2 the excision of the $\mathrm{S} 1 / \mathrm{S} 2$ and S2' subunits of the S-glycoprotein is achieved, leading to the fusion of the viral membrane with the host cell membrane achieving the endostosis of the coronavirus.
The receptors for ACE2 and TMPRSS2 are widely distributed in different tissues, mainly to respiratory tract epithelial cells, alveolar epithelial cells, vascular endothelial cells, and macrophages in the lung. However, the presence of ACE2 and TMPRSS2 receptors has been recently reported in the mouth, and in the gastrointestinal tract, in the myocardium in the kidney, and in other epithelia ${ }^{11}$. SARS-CoV-2 infection reduces the expression of ACE2 in lung cells. Since loss of ACE-2 lung function is associated with acute lung injury, virus-induced down-regulation of ACE-2 may be important for the pathology of the disease. ACE2 has been shown to regulate the renin-angiotensin system (RAS). Therefore, a reduction in ACE2 function after a SARS-CoV-2 viral infection could lead to RAS dysfunction, with elevated angiotensin II levels and increased activity of angiotensin 1-7 receptors, influencing blood pressure and fluid/electrolyte balance, inflammation and vascular permeability in the airways, vasoconstriction with increased reactive species (reactive oxygen species [ROS]), and cytokines ${ }^{12,13}$.

COVID-19 shows a difference in the mortality rate between men (2.8\%) and women (1.7\%). Since ACE2 is on the $\mathrm{X}$ chromosome, there may be alleles that confer resistance to COVID-19, which explains the lower death rate in women. One study reports lower expression of ACE-2 in the nasal mucosa of children 0.30 $(95 \% \mathrm{Cl} 0.01-0.59)$ versus $0.52(95 \% \mathrm{Cl} 0.09-0.94)$ in adults over 25 years of age $\mathrm{e}^{14}$. Alternatively, the sex hormones estrogen and testosterone have different immunoregulatory functions, which may influence the immunological protection or disease severity.

2. Replication of coronaviruses begins with the entry into the cell, at which point it loses its envelope, and the RNA genome is released into the cytoplasm.

3. The coronavirus genome has a methylated cap at the 5 ' end (cap' end) and a polyadenylated (poly A) tail at the $3^{\prime}$ end, giving it a strong resemblance to the eukaryotic messenger RNA. This allows the RNA to be attached to cytoplasmic ribosomes for translation.

4. Coronaviruses also have a replicase protein encoded in their genetic code, which allows them to generate new copies of their RNA without the need to be transcribed into DNA, using the resources of the host cell.

5. This replicase is the first protein to be synthesized because once the gene that encodes the replicase is translated (protein synthesis), the process is stopped by a stop codon. This is known as a nested 
transcript. When the mRNA transcript only encodes one gene, it is known as a monocistronic.

6. The RNA genome replicates to a negative chain, from which positive copies are formed and a long polyprotein is translated, which must be split into the various functional proteins of the virus. The coronaviruses have a protease called Mpro or $3 \mathrm{CL}$ pro that cuts the polyprotein to produce the viral proteins (polyprotein maturation).

7. This is a viral strategy for genetic economics since it allows you to code a good number of proteins with a small number of transcripts while improving the failure rate during the execution of RNA polymerase. In a normal way, in the ribosomes, the RNA is read and transformed into a sequence of amino acids that end up forming the proteins. This is where the "confusion" occurs. The human cell interprets the viral RNA as its own and follows the instructions to replicate the viral RNA as if it were its own.

8. Once the viral genetic material has multiplied, the human cell also produces the proteins that will complement the viral structure until the formation of new viruses is completed.

9. The mature virus wrapped in a protein capsule from the Golgi apparatus migrates to the cell membrane for exocytosis ${ }^{15}$.

Each coronavirus is capable of creating up to 100,000 replicates, which multiply exponentially initially in the epithelium of the upper airway: nostrils, pharynx, and larynx; subsequently, in the lower airway of the host: trachea, bronchi, and alveolar sacs.

\section{Incubation period}

The incubation period is long and varies from 0 to 14 days, with an average of 3 to 7 days. $97.5 \%$ of symptomatic COVID-19 cases will develop within 11.5 days after exposure to SARS-CoV-2. The $97.5 \%$ of the symptomatic cases develop in the 11.5 days after exposure $^{16}$.

\section{Clinical manifestations, laboratory findings, and imaging studies}

The upper airway is covered by a pseudo-layered ciliated cylindrical epithelium alternating with goblet cells, also known as the respiratory epithelium, a proper sheet of lax connective tissue with abundant vascularity, in addition to a large number of plasma cells, mast cells, macrophages, and lymphocytes. The respiratory region has the function of heating and humidifying the inspired air, as well as filtering airborne particles $^{17}$.

Transmission of the SARS-CoV-2 infection is currently considered to begin 1-2 days before the onset of symptoms.

It is not known whether the intensity of transmission from asymptomatic persons will be the same as from persons with symptoms, although the viral load detected in one asymptomatic case was similar to that of other symptomatic cases $^{18}$. Transmission of the infection would occur primarily in mild cases in the $1^{\text {st }}$ week of symptom onset, from 1 to 2 days before to 5 to 6 days after. In more severe cases, transmission would be more intense and long-lasting. After a clinical cure, the possibility of transmission is small, but some cases have been reported with the presence of the virus in oropharyngeal smears (reverse transcription-polymerase chain reaction [RT-PCR] +) in the convalescent phase after discharge with cure and after two negative RT-PCR tests ${ }^{19}$.

The pathophysiology of a SARS-CoV-2 infection closely resembles that of SARS-CoV infection, with aggressive inflammatory responses strongly implicated in the resulting damage to the respiratory tract. Therefore, the severity of the disease in patients is due not only to the viral infection but also to the host response. Thus, the first symptoms will be fever, rhinorrhea, odynophagia, dry cough, and muscle pain for several days. If the infection progresses to the lower respiratory tract, after 7 days, the fever persists, the cough can be productive, the patient may present dyspnea on great exertions and to lesser degree symptoms of the digestive system such as nausea, vomiting, diarrhea, and others such as headache, olfactory, and gustatory dysfunctions (anosmia and ageusia). In this stage, laboratory and cabinet studies are indispensable and the following are reported as frequent findings: lymphopenia and thrombocytopenia, with elevation of C-reactive protein, D-dimer and ferritin, interleukin 6 (IL-6), and procalcitonin (Fig. 4) ${ }^{20}$.

The diagnosis of COVID-19 must be confirmed by RT-PCR or by sequencing the viral genome in samples of upper airway secretions, as a parameter for deciding and according to the clinical picture, the hospitalization of the patient ${ }^{21}$. In Mexico, $39.15 \%$ of the cases of Covid-19 have required hospitalization.

$\lg$ antibodies have been reported positive in $60 \%$ of asymptomatic patients and $87.1 \%$ in symptomatic patients in the convalescent phase (Table 2) ${ }^{22}$. These data indicate that the immune response plays a role in the cure in up to $80-90 \%$ of cases of patients infected 


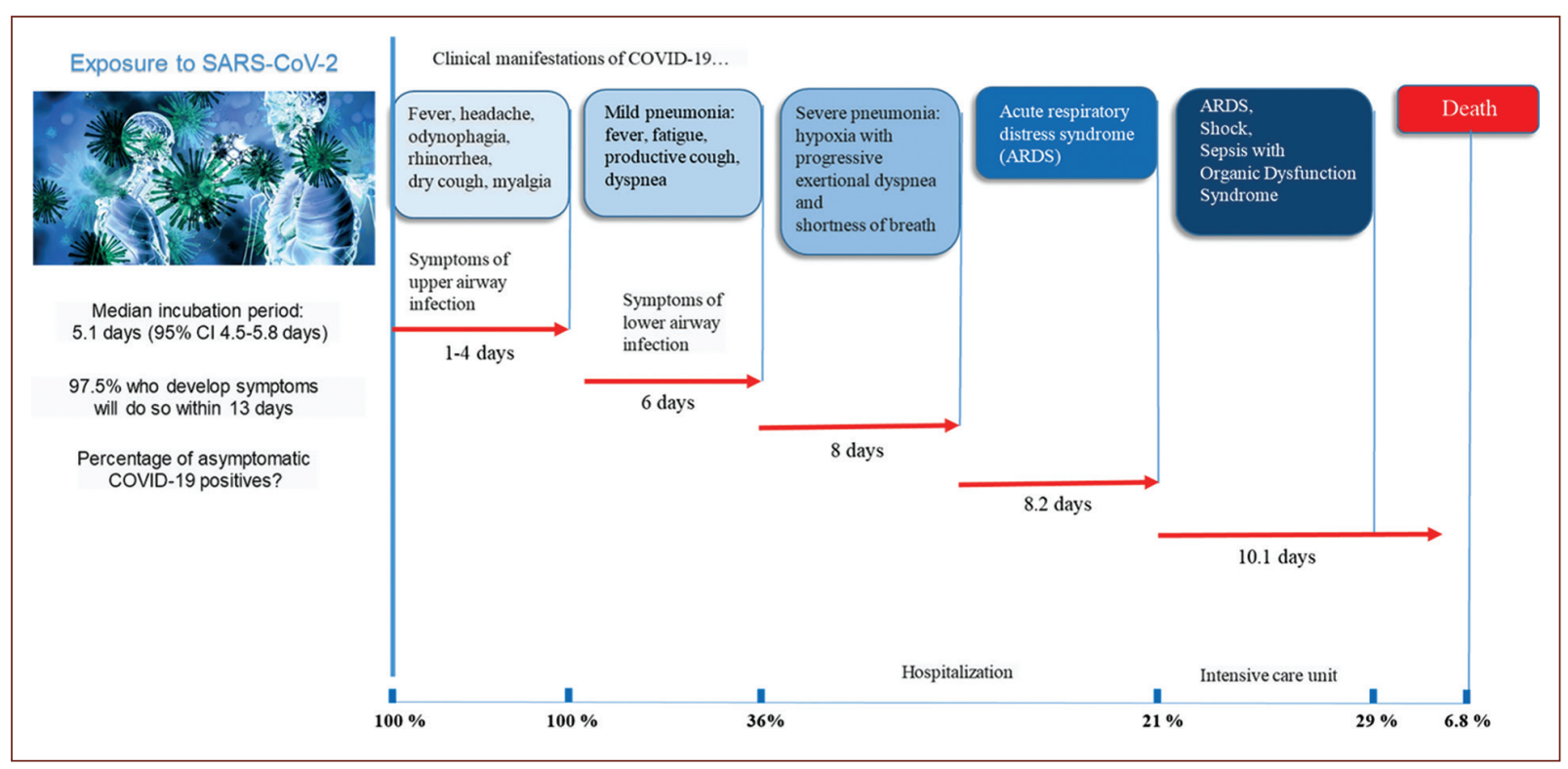

Figure 4. Evolution of the clinical presentation of COVID-19.

Table 2. Sensitivity of immunological tests for SARS-CoV-2

\begin{tabular}{|l|c|c|c|}
\hline SARS-CoV-2 test & $\mathbf{1 - 7}$ days & $\mathbf{8 - 1 4}$ days & $\mathbf{1 5 - 3 9}$ days \\
\hline RNA by RT-PCR & $67.1 \%$ & $54.0 \%$ & $45.5 \%$ \\
\hline Total antibodies & $38.3 \%$ & $89.6 \%$ & $100 \%$ \\
\hline IgM & $28.7 \%$ & $73.3 \%$ & $94.3 \%$ \\
\hline IgG & $19.1 \%$ & $54.1 \%$ & $79.8 \%$ \\
\hline
\end{tabular}

RNA: ribonucleic acid; RT-PCR: reverse transcriptase-polymerase chain reaction; $\lg \mathrm{M}$ and $\lg \mathrm{G}$ enzyme-linked immunizer bent assay (ELISA).

by the SARS-CoV-2 coronavirus, coupled with elevated T cells (CD4 + helper T lymphocyte and CD8 + cytotoxic T lymphocyte) ${ }^{23}$.

The tele chest or chest computed tomography (CT) scan reports the presence of opacities like polished glass with predominance in both of the lower pulmonary lobes ${ }^{24}$.

A Chest CT is considered an important tool if symptoms worsen or in an environment with limited resources for RT-PCR. Findings obtained in a non-contrast chest CT allows a diagnostic performance using the COVID-19 reporting and data system (CO-RADS) evaluation: CO-RADS could distinguish between patients with PCR + from those with PCR- with an average area under the curve (AUC) of $0.91(95 \% \mathrm{Cl}, 0.85-0.97)$. The average AUC increased to $0.95(95 \% \mathrm{Cl}, 0.91-0.99)$ if a clinical diagnosis of COVID-19 was also accepted. The proportion of cases with a positive PCR or clinical diagnosis of COVID-19 increased from CO-RADS 1-5. - CO-RADS 1. Involves a very low level of suspicion for COVID-19 with a normal chest CT or even with the finding of mild or severe emphysema, peripheral nodules, lung tumors, or fibrosis.

- CO-RADS 2. Involves a low level of suspected pulmonary involvement by COVID-19 based on CT findings in the lungs that are typical of infectious etiology that are considered non-compatible with COVID-19. Examples are bronchitis, infectious bronchiolitis, bronchopneumonia, lobar pneumonia, and lung abscess.

- CO-RADS 3. Involves equivocal findings of pulmonary involvement by COVID-19 based on CT characteristics that can also be found in other viral pneumonias or non-infectious etiologies. Findings include perihilar ground-glass, extensive homogeneous ground-glass with or without preservation of some secondary pulmonary lobes, or ground-glass along with smooth interlobular septal thickening.

- CO-RADS 4. Involves a high level of suspected lung involvement by COVID-19 based on CT findings that are typical of COVID-19 but show some overlap with other (viral) pneumonias. The findings are not in contact with the visceral pleura or are strictly unilateral, they have a predominant peribronchovascular distribution or overlap with severe and diffuse pre-existing pulmonary abnormalities. 


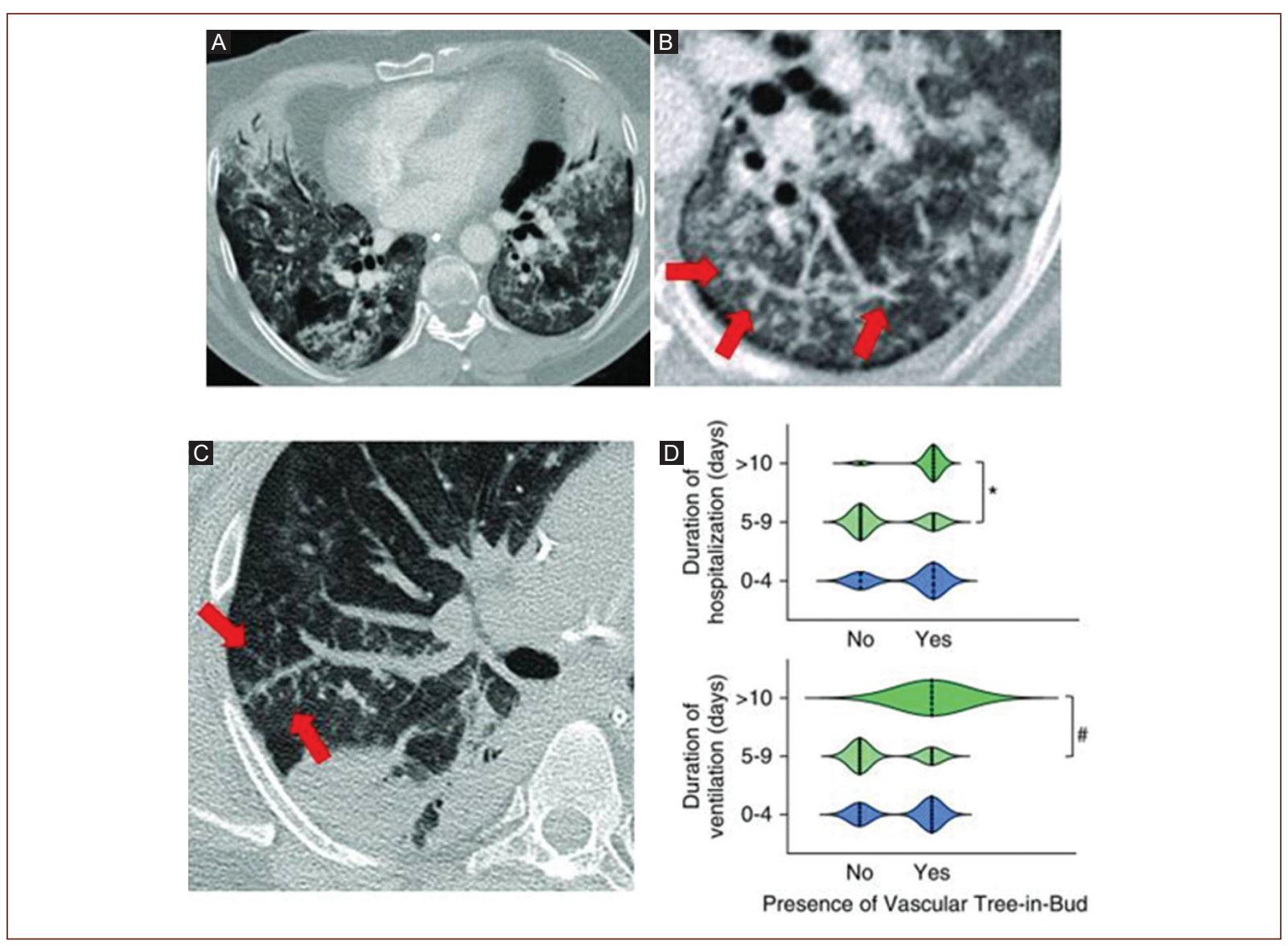

Figure 5. A-D: Computed tomography pulmonary angiography showing ground-glass opacification and consolidation with "vascular tree-in-bud-pattern" of patients with pneumonia from COVID-19.

- CO-RADS 5. Involves a very high level of suspicion of pulmonary involvement by COVID-19 according to typical CT findings. Mandatory features are groundglass opacities, with or without consolidations, in pulmonary regions near visceral pleural surfaces, including fissures, and multifocal bilateral distribution. It was found that the lower lobe predominance described above is often not present in positive RT-PCR cases, and therefore, lower lobe predominance was excluded as a required feature. Subpleural curvilinear bands or ground-glass bands with or without consolidation in an arc pattern tied with small connections to the pleura are also considered typical. Thickened vessels within the pulmonary anomalies are typical with "vascular tree bud pattern" (Fig. 5) ${ }^{25,26}$.

Fever, a temperature $>38^{\circ} \mathrm{C}$, persists for $4-12$ days in survivors, dyspnea is reported with a median of 13 days and cough persists with a median of 19 days and may persist in up to $45 \%$ of hospitalized patients after discharge. Cough is reported in $72 \%$ of fatal cases ${ }^{27,28}$.

Respiratory function may change from mild to severe within a few days or the patient may require assisted ventilation between 3 and 12.5 days after the onset of symptoms with a median of 10 days. The severe complications that require a patient to be transferred to the intensive care unit are ARDS, multiple organ dysfunction syndrome due to sepsis, and/or septic shock (Tables 3-5) 29-33.

In ARDS, three stages or phases in the pathological evolution of the lung lesion are described: the exudative phase, the proliferative phase, and the fibrotic phase, with a mortality rate of over $80 \%^{34-36}$.

The exudative phase occurs within the first few hours of the lung injury. When the SARS-CoV-2 virus infects the type II pneumocytes that express the surface receptors of the enzyme ACE2 and TMPRSS2, active replication and the release of the virus causes 
Table 3. Severity levels and evolution of COVID-19

\begin{tabular}{|c|c|}
\hline Severity levels and evolution & Clinical, laboratory, and radiological findings \\
\hline $\begin{array}{l}\text { Phase I } \\
\text { - Uncomplicated disease }\end{array}$ & Fever, rhinorrhea, odynophagia, cough, myalgia, and headache \\
\hline $\begin{array}{l}\text { Phase II or pulmonary phase } \\
\text { - Mild pneumonia }\end{array}$ & Confirmed with a chest X-ray or CT scan (CO-RADS 2-3). $\mathrm{SaO}_{2}>90 \%$. RT-PCR + \\
\hline - Severe pneumonia & $\begin{array}{l}\text { Severe pneumonia fever, productive cough, dyspnea. Chest CT scan (CO-RADS 4-5). } \\
\mathrm{SaO}_{2}<90 \% \text { and tachypnea } \geq 30 / \mathrm{min} \text {. RT-PCR }+\operatorname{IgM}+, \operatorname{IgG}+ \\
\text { Lymphopenia }<0.8 \times 10^{9} / \mathrm{L} \text {. Thrombocytopenia }<100 \times 10^{9} / \mathrm{L} \text { D-dimer elevation } \\
>1 \mu \mathrm{g} / \mathrm{L} \text {. PCR elevation } \\
\text { Ferritin elevation }>300 \mu \mathrm{g} / \mathrm{L} \\
\mathrm{IL}-6 \text { elevation }>7.4 \mathrm{pg} / \mathrm{mL} \\
\text { Procalcitonin elevation } \geq 0.5 \mathrm{ng} / \mathrm{mL}\end{array}$ \\
\hline $\begin{array}{l}\text { Phase III or hyper-inflammatory phase } \\
\text { - Acute respiratory distress syndrome (ARDS) }\end{array}$ & $\begin{array}{l}\text { Cough, dyspnea. Chest CT with bilateral ground-glass opacities, with hypoxia: } \\
\text { - Mild: } 200 \mathrm{mmHg}<\mathrm{PaO}_{2} / \mathrm{FiO}_{2} \leq 300 \\
\text { - Moderate: } 100 \mathrm{mmHg}<\mathrm{PaO}_{2} / \mathrm{FiO}_{2} \leq 200 \\
\text { - Severe: } \mathrm{PaO}_{2} / \mathrm{FiO}_{2} \leq 100 \mathrm{mmHg}^{2}\end{array}$ \\
\hline $\begin{array}{l}\text { - Multiple organ dysfunction syndrome by } \\
\text { septicemia }\end{array}$ & $\begin{array}{l}\text { Organic dysfunction on the SOFA Score }>2 \text { points or an acute change in the Quick } \\
\text { Sofa with }>2 \text { criteria }\end{array}$ \\
\hline - Septic shock & $\begin{array}{l}\text { Arterial hypotension that persists despite volume replacement with solutions and } \\
\text { requires vasopressors to maintain } \mathrm{MAP} \geq 65 \mathrm{mmHg} \text { and lactate } \geq 2 \mathrm{moll} / \mathrm{L}(18 \mathrm{mg} / \mathrm{dL} \text { ) } \\
\text { in the absence of hypovolemia }\end{array}$ \\
\hline
\end{tabular}

CO-RADS (COVID-19 Reporting and Data System): standardized assessment scale for lung involvement from COVID-19 in a chest computed tomography (CT); Sa $0_{2}$ : arterial oxygen saturation; RT-PCR: reverse transcriptase-polymerase chain reaction test; CRP: C-reactive protein; IL-6: interleukin 6; $\mathrm{PaO}_{2}$ : arterial pressure of oxygen; $\mathrm{FiO}_{2}$ : fraction of inspired oxygen; SOFA: Sequential Organ Failure Assessment; MAP: mean arterial pressure.

Table 4. Sequential organ failure assessment score

\begin{tabular}{|c|c|c|c|c|c|}
\hline Criteria & 0 & +1 & +2 & +3 & +4 \\
\hline $\begin{array}{l}\text { Respiration } \\
\mathrm{PaO}_{2} / \mathrm{FIO}_{2}(\mathrm{mmHg}) \mathrm{SaO}_{2} / \mathrm{FIO}_{2}\end{array}$ & $>400$ & $<400221-301$ & $<300142-220$ & $<20067-141$ & $<100<67$ \\
\hline $\begin{array}{l}\text { Coagulation } \\
\text { Platelets } 10^{3} / \mathrm{mm}^{3}\end{array}$ & $>150$ & $<150$ & $<100$ & $<50$ & $<20$ \\
\hline $\begin{array}{l}\text { Liver } \\
\text { Bilirubin (mg/dL) }\end{array}$ & $<1.2$ & $1.2-1.9$ & $2.0-5.0$ & $6.0-11.9$ & $>12.0$ \\
\hline $\begin{array}{l}\text { Cardio-vascular } \\
\text { Mean Arterial Pressure }\end{array}$ & $\begin{array}{l}\text { MAP } \geq \\
70 \mathrm{mmHg}\end{array}$ & $\begin{array}{l}\mathrm{MAP}< \\
70 \mathrm{mmHg}\end{array}$ & $\begin{array}{c}{ }^{*} \text { Dopamine } \\
<5 \text { *Dobutamine }\end{array}$ & $\begin{array}{c}{ }^{*} \text { Dopamine } 5-15 \\
{ }^{*} \text { Epinephrine } \leq 0.1 \\
{ }^{*} \text { Norepinephrine } \leq 0.1\end{array}$ & $\begin{array}{c}\text { *Dopamine }>15 \\
{ }^{*} \text { Epinephrine }>0.1 \\
\text { * Norepinephrine }>0.1\end{array}$ \\
\hline $\begin{array}{l}\text { Central nervous system } \\
\text { Glasgow Coma Score }\end{array}$ & 15 & $13-14$ & $10-12$ & $6-9$ & $<6$ \\
\hline $\begin{array}{l}\text { Renal } \\
\text { Creatinine }(\mathrm{mg} / \mathrm{dL}) \text { Urine } \\
\text { Output }(\mathrm{mL} / \mathrm{d})\end{array}$ & $<1.2$ & $1.2-1.9$ & $2.0-3.4$ & $3.5-4.9<500$ & $>5.0<200$ \\
\hline
\end{tabular}

$\mathrm{PaO}_{2}$ : arterial pressure of oxygen; $\mathrm{FiO}_{2}$ : fraction of inspired oxygen; Sa02: arterial oxygen saturation; MAP: mean arterial pressure; $\mathrm{PaO}_{2} / \mathrm{FiO}_{2}$ preferred ratio since $\mathrm{SaO}_{2} / \mathrm{FiO}_{2}$ is not available: ${ }^{*}$ Vasoactive drugs administered for at least $1 \mathrm{~h}$ (dopamine and norepinephrine as ug/kg/min), to maintain MAP above $65 \mathrm{mmHg}$. Lactate measurement did not increase its predictive validity but may help in identifying patients at intermediate risk.

the host cell to undergo pyroptosis which is a highly inflammatory form of programmed cell death that occurs most often after infection with intracellular pathogens and that unlike apoptosis, pyroptosis requires the function of the enzyme Caspase- 1 which is activated during pyroptosis by a large supramolecular complex called a pyroptosome (also known as an inflammasome).

Only one large pyroptosome is formed in each macrophage within minutes of infection and is largely 


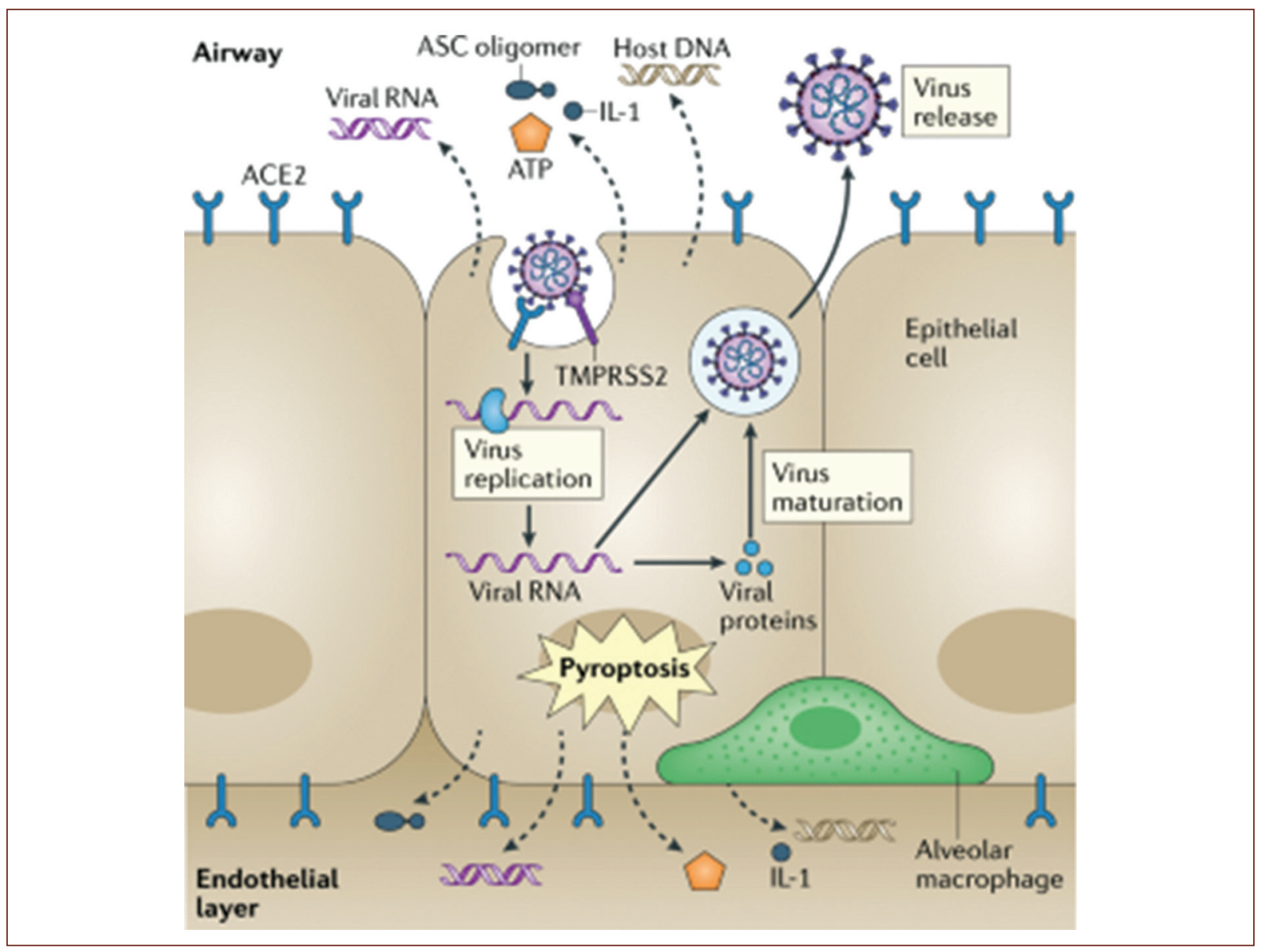

Figure 6. Pathophysiology of severe acute respiratory distress syndrome due to SARS-CoV-2 infection.

Table 5. Quick SOFA

\begin{tabular}{|l|l|}
$\begin{array}{l}\text { - Alteration in level of } \\
\text { consciousness }\end{array}$ & Glasgow coma score $\leq 13$ \\
\hline - Systolic blood pressure & $\leq 100 \mathrm{mmHg}$ \\
\hline - Respiratory rate & $\geq 22 / \mathrm{min}$ \\
\hline
\end{tabular}

composed of the oligomers of the adaptive protein ASC, a speck-like protein associated with apoptosis (Fig. 6) ${ }^{36}$.

These are recognized by neighboring epithelial cells, endothelial cells, and alveolar macrophages, which triggers the generation of cytokines: IL-2, IL-6, IL-10, pro-inflammatory chemokines (CXCL-10 known as IP-10), hematopoietins such as the macrophage inflammatory protein $1 \alpha$ and $1 \beta$ (MIP1 $\alpha$, MIP1 $\beta)$ and the monocyte chemoattractant protein-1 or granulocyte colony-stimulating factor. These proteins attract monocytes, macrophages, and $T$ cells to the site of infection, promoting further inflammation (with the addition of interferon-gamma, IFN $\gamma$, produced by the T cells) and establishing a pro-inflammatory feedback loop. In a faulty immune response, this can lead to a further buildup of immune cells in the lungs, causing an overproduction of pro-inflammatory cytokines, which eventually damage the lung infrastructure. The resulting cytokine storm circulates to other organs, causing damage to multiple organs (Fig. 7$)^{37}$

In addition, non-neutralizing antibodies produced by B cells can promote SARS-CoV-2 infection through antibody-dependent enhancement, further exacerbating organ damage.

These histopathology microscope images show the presence of viral elements within the endothelial cells and an accumulation of inflammatory cells, with evidence of inflammation and endothelial cell death ${ }^{38}$.

These findings suggest that infection by SARS-CoV-2 facilitates the induction of endothelial dysfunction in various organs as a direct result of viral involvement and the host's inflammatory response. In addition, induction 


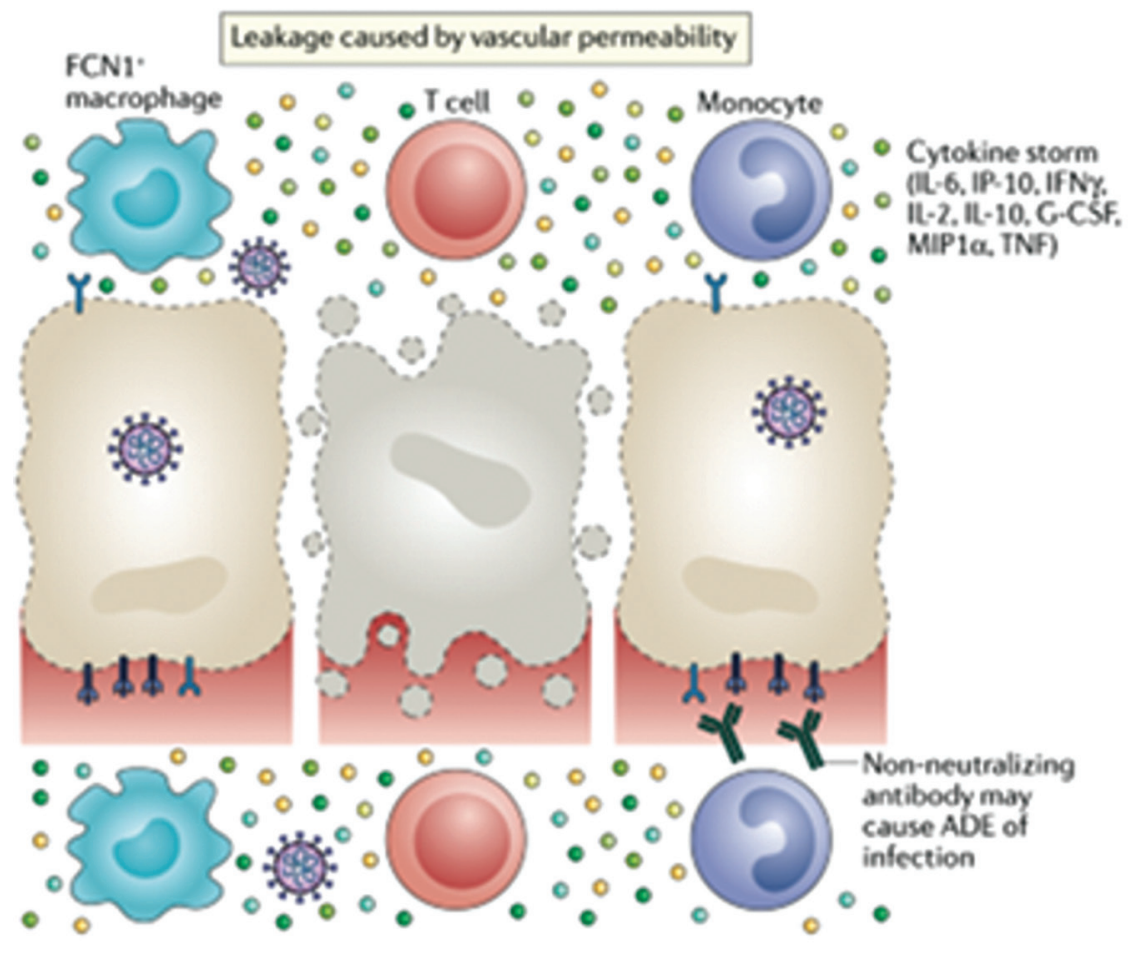

\section{Dysfunctional inmune response: \\ - Excessive infiltration of monocytes, macrphages an $\mathrm{T}$ cells \\ - $\quad$ Systemic cytokine storm \\ - Pulmonary oedema and pneumonia \\ - Widespread inflammation and multi-organ damage}

Figure 7. Pathophysiology of endotheliitis in the alveolar-endothelial space in acute respiratory distress syndrome due to SARS-CoV-2 infection.

of apoptosis and pyroptosis may have an important role in endothelial cell injury in patients with COVID-19. Endotheliitis due to COVID-19 may explain the systemic microcirculatory dysfunction in different vascular beds and its clinical sequelae in COVID-19 patients. This hypothesis provides a justification for therapies to stabilize the endothelium while addressing viral replication ${ }^{39}$.

This strategy may be particularly relevant for vulnerable patients with pre-existing endothelial dysfunction, which is associated with age, male sex, smoking, hypertension, diabetes, obesity, the established cardiovascular disease, and OSA, all of which are associated with adverse outcomes in COVID-19.

\section{Funding}

This research has not received any specific grant from public, commercial, or non-profit agencies.

\section{Conflicts of interest}

None.

\section{Ethical disclosures}

Protection of human and animal subjects. The authors declare that no experiments were performed on humans or animals for this study.

Confidentiality of data. The authors declare that they have followed the protocols of their work center on the publication of patient data.

Right to privacy and informed consent. The authors declare that no patient data appear in this article.

\section{References}

1. Hernández G. SARS: epidemiología y mecanismos de transmisiòn. Med Intensiva. 2003;27:686-91. 


\section{Rivera-Castaño: OSA is a risk comorbidity for COVID-19 fatality. Part I}

2. Gorbalenya AE, Baker SC, Baric RS, Baric RS, de Groot RJ, Drosten C, et al. The species severe acute respiratory syndrome-related Coronavirus: classifying 2019-nCoV and naming it SARS-CoV-2. Nat Microbiolol. 2020;5:536-44.

3. Kumar S, Nyodu R, Maurya VK, Saxena SK. Morphology, genome organization, replication, and pathogenesis of severe acute respiratory syndrome Coronavirus 2 (SARS-CoV-2). In: Saxena SK, editors. Coronavirus Disease 2019 (COVID-19). Singapore: Springer; 2020. p. 23-31.

4. Yan R, Zhang Y, Li Y, Xia L, Guo Y, Zhou Q. Structural basis for the recognition of SARS-CoV-2 by full-length human ACE2. Science. 2020;367:1444-8.

5. Lan J, Ge J, Yu J, Shan S, Zhou H, Fan S, et al. Structure of the SARS-CoV-2 spike receptor-binding domain bound to the ACE2 receptor Nature. 2020;581:215-20.

6. Hoffmann M, Kleine-Weber $H$, Schroeder S, Krüger N, Herrler T, Erichsen S, et al. SARS-CoV-2 cell entry depends on ACE2 and TMPRSS2 and is blocked by a clinically proven protease inhibitor. Cell. 2020;181:271-80.

7. Nie X, Fan L, Mu G, Tan Q, Wang M, Xie Y, et al. Epidemiological characteristics and incubation period of 7,015 confirmed cases with Coronavirus disease 2019 outside Hubei province in China. J Infect Dis. 2020;222:26-33

8. Li Q, Guan X, Wu P, Wang X, Zhou L, Tong Y, et al. Early transmission dynamics in Wuhan, China, of Novel Coronavirus-infected pneumonia. $N$ Engl J Med. 2020;382:1199-207.

9. Sanche S, Lin YT, Xu C, Romero-Severson E, Hengartner N, Ke R. High contagiousness and rapid spread of severe acute respiratory syndrome Coronavirus 2. Emerg Infect Dis. 2020;26:1470-7.

10. Javier C. Agente causal: SARS-CoV-2. In: Ezpeleta D, García-Azorin D, editors. Manual COVID-19 para el Neurólogo General. Madrid: Sociedad Española de Neurología; 2020. p. 13-7.

11. Xu H, Zhong L, Deng J, Peng J, Dan H, Zeng X, et al. High expression of ACE2 receptor of 2019-nCoV on the epithelial cells of oral mucosa. Int J Oral Sci. 2020;12:8.

12. Vaduganathan M, Michel T, McMurray JJ, Pfeffer MA, Solomon SD. Renin-angiotensin-aldosterone system inhibitors in patients with COVID-19. N Engl J Med. 2020;382:1653-9.

13. Gheblawi M, Wang K, Viveiros A, Nguyen Q, Zhong JC, Turner AJ, et al Angiotensin-converting enzyme 2: SARS-CoV-2 receptor and regulator of the renin-angiotensin system: celebrating the $20^{\text {th }}$ anniversary of the discovery of ACE2. Circ Res. 2020;126:1457-75.

14. Bunyavanich $S$, Do A, Vicencio A. Nasal gene expression of angiotensin-converting enzyme 2 in children and adults. JAMA. 2020;323:2427-9.

15. Fung S, Liu DX. Human Coronavirus: host-pathogen interaction. Annu Rev Microbiol. 2019;73:529-57.

16. Lauer SA, Grantz KH, Bi Q, Jones FK, Zheng Q, Meredith HR, et al. The incubation period of Coronavirus disease 2019 (COVID-19) from publicly reported confirmed cases: estimation and application. Ann Intern Med 2020;172:577-82

17. Respiración L. In: Hall JE, editors. Guyton y Hall. Compendio de Fisiología Médica. $13^{\text {th }}$ ed., Barcelona. Elsevier 2016: Ch. 38-42.

18. Gandhi M, Yokoe DS, Havlir DV. Asymptomatic transmission, the AchiIles' heel of current strategies to control COVID-19. N Engl J Med. 2020;382:2158-60.

19. Chen N, Zhou M, Dong X, Qu J, Gong F, Han Y, et al. Epidemiological and clinical characteristics of 99 cases of 2019 Novel Coronavirus pneumonia in Wuhan, China: a descriptive study. Lancet. 2020;395:507-13.

20. Guan W, Ni Z, Hu Y, Liang W, Ou C, He J, et al. Clinical characteristics of Coronavirus disease 2019 in China. N Engl J Med. 2020;382:1708-20.

21. Zhao J, Yuan Q, Wang H, Liu W, Liao X, Su Y, et al. Antibody responses to SARS-CoV-2 in patients of Novel Coronavirus disease 2019. Clin Infect Dis. 2020;71:2027-34
22. Long $Q X$, Tang $X J$, Shi QL, Li Q, Deng HJ, Yuan J, et al. Clinical and immunological assessment of asymptomatic SARS-CoV-2 infections. Nat Med. 2020;26:1200-4.

23. Sethuraman N, Stanleyraj S, Ryo A. Interpreting diagnostic tests for SARS-CoV-2. JAMA. 2020;323:2249-51.

24. Zhao W, Zhong Z, Xie X, Yu Q, Liu J. Relation between chest CT findings and clinical conditions of Coronavirus disease (COVID-19) pneumonia: a multicenter study. AJR Am J Roentgenol. 2020;214:1072-7.

25. Prokop $M$, van Everdingen $W$, van Rees Vellinga $T$, van Ufford $H Q$, Stöger L, Beenen L, et al. CO-RADS: a categorical CT assessment scheme for patients suspected of having COVID-19-definition and evaluation. Radiology. 2020;296:E97-104.

26. Patel BC, Arachchillage DJ, Ridge, CA, Bianchi P, Doyle JF, Garfield B, et al. Pulmonary angiopathy in severe COVID-19: physiologic, imaging, and hematology observations. Am J Respir Crit Care Med. 2020;202: 690-9.

27. Zhou F, Yu T, Du R, Fan G, Liu Y, Liu Z, et al. Clinical course and risk factors for mortality of adult inpatients with COVID-19 in Wuhan, China: a retrospective cohort study. Lancet. 2020;395:1054-62.

28. Bi Q, Wu Y, Mei S, Ye C, Zou X, Zhang Z, et al. Epidemiology and transmission of COVID-19 in 391 cases and 1286 of their close contacts in Shenzhen, China: a retrospective cohort study. Lancet Infect Dis. 2020;20:911-9.

29. Wu C, Chen X, Cai Y, Xia J, Zhou X, Xu S, et al. Risk factors associated with acute respiratory distress syndrome and death in patients with Coronavirus disease 2019 pneumonia in Wuhan, China. JAMA Intern Med. 2020;180:934-43.

30. Singer M, Deutschman CS, Warren-Seymour C, Shankar-Hari M, Annane $D$, Bauer $M$, et al. The third international consensus definitions for sepsis and septic shock (sepsis-3). JAMA. 2016;315:801-10.

31. Monares ZE, Rodríguez GJ, Valles GA, Galindo MC, Corrales BE, Suárez CA. Validación de la «escala evaluación de fallo orgánico secuencial» (SOFA) con modificación del componente cardiovascular en la Unidad de Terapia Intensiva del Hospital San Ángel Inn Universidad. Med Crit. 2016;30:319-23.

32. Churpek MM, Snyder A, Han X, Sokol S, Pettit N, Howell MD, et al. Quick sepsis-related organ failure assessment, systemic inflammatory response syndrome, and early warning scores for detecting clinical deterioration in infected patients outside the intensive care unit. Am J Respir Crit Care Med. 2017;195:906-11.

33. Ortiz-Brizuela E, Villanueva-Reza M, González-Lara MF, Tamez-Torres KM, Román-Montes CM, Díaz-Mejía BA, et al. Clinical and epidemiological characteristics of patients diagnosed with COVID-19 in a tertiary care center in Mexico City: a prospective cohort study. Rev Invest Clin. 2020;72:165-77.

34. Thompson T, Chambers RC, Liu KD, Acute respiratory distress syndrome. N Engl J Med. 2017;377:562-72.

35. Matthay MA, Zemans RL, Zimmerman GA, Arabi YM, Beitler JR, Mercat $A$, et al. Acute respiratory distress syndrome. Nat Rev Dis Primers. 2019;5:18

36. Xu Z, Shi L, Wang Y, Zhang J, Huang L, Zhang C, et al. Pathological findings of COVID-19 associated with acute respiratory distress syndrome. Lancet Respir Med. 2020:8:420-2.

37. Tay MZ, Poh CM, Rénia L, Ary PA, Ng LF. The trinity of COVID-19: immunity, inflammation and intervention. Nat Rev Immunol. 2020;20: 363-74.

38. Varga Z, Flammer AJ, Steiger P, Haberecker M, Andermatt R, Zinkernagel AS, et al. Endothelial cell infection and endotheliitis in COVID-19. Lancet. 2020;395:1417-8.

39. Ackermann M, Verleden SE, Kuehnel M, Haverich A, Welte T, Laenger F, et al. Pulmonary vascular endothelialitis, thrombosis, and angiogenesis in COVID-19. N Engl J Med. 2020;383:120-8. 